\title{
Will Final Year Accountancy Students Whistle Blow? A Malaysian Case
}

\author{
Mazlina Mustapha and Ling Sing Siaw
}

\begin{abstract}
This paper aims to explore the ethical views of final year accountancy students in Malaysia. Specifically, this study seeks to investigate the final year accountancy students' perception on whistle blowing and the likelihood of blowing the whistle in relation to seriousness of questionable act, gender, race and academic performance. About 150 questionnaires were distributed to final year accountancy students in a public university in Malaysia; however, only 105 questionnaires were usable and completed to be used in the study. Majority of the respondents are taking a relatively moderate approach towards their willingness to blow the whistle. The regression result reveals that the seriousness of the unethical act has a significant and positive relationship with the probability of blowing the whistle by these students. In addition, the result appears to suggest that high academic achiever have a negative relationship with the probability of blowing the whistle.
\end{abstract}

Index terms-Ethics, final year accountancy students, whistle blowing, Malaysia.

\section{INTRODUCTION}

Following the worldwide corporate scandals in the US and Europe, public scrutiny of accountants decisions have increased. More attention is directed to the ethicality of the accountants' actions [15]. Ethical conduct has been recognized as an important element in accounting profession and education [1]. It is believed that professionalism and ethics should be upheld.

One of the areas of interest relating to ethic is whistle blowing. Whistle blowing is defined as the disclosure by an organization's member of any illegal, immoral or illegitimate practices under the control of their employers to a person that may be able to affect action [8]. After the Enron case, perception on whistle blowing beginning to change, whistle blowing is now viewed as an accountability and risk management tool that can be used to safeguard the interest of the company and public [11]. It is also claimed that there has been a substantial increase in the recognition of the importance of whistle blowing as a mean of reducing corruption and dangerous situations by improving the disclosure of information about illegal, dangerous or unethical activities by government and private organization [4].

Countries around the world are now working to develop legal regimes to encourage these important disclosures and

Manuscript received July 10, 2012; revised August 15, 2012.

Mazlina Mustapha is a senior lecturer at Department of Accounting and Finance, Faculty of Economics and Management, Universiti Putra Malaysia, Serdang, Selangor, Malaysia (e-mail: mazlina05@gmail.com )

Ling Sing Siaw is an accounting graduate from Faculty of Economics and Management, Universiti Putra Malaysia, Serdang, Selangor, Malaysia. protect the whistle blowers from retribution [4]. Over 30 countries have now adopted specific whistle blower protections, while others have adopted protections through other laws such as labor laws or public sector employment rules [4]. In Malaysia, a whistleblower provision is found in the Companies Act 1965. Subsection 174(8) of the act requires auditors to report to the Companies Commission of Malaysia, if the auditor encountered a breach or noncompliance with any provision of the Company Act in the course of the statutory audit. The requirements to report breaches of laws are often referred as the "whistle-blowing" duty. Section 50 and 99E of the Securities Industry Act 1983 also require auditors to report breaches of securities law to the authorities.

Although interest in whistle blowing continues to increase, little is known about why some employees who observe wrong doing report it, while others do not [16]. In an attempt to address the public's concerns, the accounting profession has emphasized the need to start ethics education early in an accountant's career, even before he or she enters the profession [17]. Prior studies on how accounting students react to whistle blowing is limited and mostly conducted outside Malaysia. This reveals the need to further investigate this issue. Thus, this study is conducted to examine the final year accountancy students' perception on whistle blowing and their likelihood to blow the whistle.

The remainder of the paper is structured as follows. Section II gives a review of the relevant literature and Section III describes the sample and methodology used for the study. Section IV presents and discusses the empirical results and, finally Section $\mathrm{V}$ provides the conclusions of the study.

\section{LITERATURE REVIEW}

Whistle blowing is defined as the disclosure by an organization's member of any illegal, immoral or illegitimate practices [8] or a person who discloses significant acts of corruptions, waste, fraud, mismanagement or abuse of authority in contravention of the country's laws or regulations in either the public or private sector [11]. Another study defines whistle blower as a subversive spy or responsible corporate citizen who has the courage to do as their conscience dictates [3]. Those who report individual or organizational violations of federal or state laws to their supervisors or the government face major risks, and individuals who wish to report alleged wrong doing should take great pause while considering the potential ramifications of the decision before notifying authorities or superiors of the misconduct [5].

Whistle blowing is a complex process that involves 
personal and organizational factors. Significant research has investigated the antecedents of whistle blowing. [17] concludes that students generally feel that whistle blowing is necessary in cases of fraud, although they are less likely to do it themselves, probably due to the high costs involved such as retaliation and the difficulty of finding a future job in the same profession. It is also claimed that auditing students are more likely to perceive whistle blowing as serious and more likely to blow the whistle compared to other students. These results have emphasized the need for professionals to develop ethical attitudes early in their career, even before they enter the profession.

Reference [14] examined the ethical attitudes of final year accountancy students in Ireland and Australia. Students were surveyed as to whether they would accept a bribe and/or cheat in an exam. Their attitudes towards whistle blowing if they became aware of improprieties were also reviewed. Among the students, 58 per cent of Irish and 23 per cent of Australian appeared willing to participate in fraud. These percentages plummeted when the risk of being caught was introduced. Males appeared between two and four times more likely than females to act unethically. Just greater than 50 per cent of Australian and just fewer than 50 per cent of Irish students appeared willing to be whistleblowers.

Before an individual would consider responding to an issue of principle, the issue must be serious enough to warrant consideration of response [6]. Seriousness is an evaluation of the issue, influenced by the characteristics of the situation and others involved, including such concerns as likelihood of harm to others, significance or magnitude of potential harm, certainty of negative outcomes and frequency of such wrongdoing [6]. Besides, observer will be more likely to blow the whistle when such action is expected to result in the desired change in managerial behavior [12]. [12] further find that the seriousness of a wrongdoing, operationalized as its dollar value, is positively related to whistle-blowing activities among U.S. government employees. This is supported by [13] who claims that the frequency of an observed wrongdoing is related to whistle-blowing behaviour; the consequences of more frequent activities may be easier to predict based on past experience. [6] finds that perceived seriousness is positively associated with whistle-blowing intentions. In addition, the type of wrongdoing and its perceived severity has been found to be positively related to whistle blowing [13].

Previous whistle blowing studies have also used gender in predicting the individual intention to whistle blow. Previous studies show that men and women differ significantly in making ethical judgments. With regards to whistle blowing, studies have found that women are less likely than men to engage in whistle blowing acts [2]. Males may have more opportunities to observe wrongdoing, because as a group they are more widely distributed across different job categories than are females, who tend to be occupationally [12]. If whistle blowing is viewed as behaviour deviating from majority opinion, then females should be less likely to blow the whistle than should males [12], [16]. In terms of ethical values relating to gender, Pierce $\&$ Sweeney find that females are more ethical than males in terms of their intentions and judgments. Male students are also claimed to indulge more in unethical manner compare to female and female are more inclined towards making ethical judgment [1]. A survey done by [14] also shows that male student significantly more likely to act unethically as opposed to their female counterparts.

Research regarding races and academic performance of accounting students and their ethic values are limited. It is claimed that a student with higher education degree is more likely to blow the whistle [16]. [1] conduct a study relating to students cheating in examination. They find that good students are less likely to cheat in examinations as compared to those with lower grades. A survey done by [17] noted that student would more likely to perceive whistle blowing as serious and more likely to blow the whistle when they are professionally committed auditing students. [18] emphasized the important of developing professional commitment among accounting students. She concluded that the nature and frequency of contact with faculty members were significantly related to professional commitment among accounting students. The important of frequent contacts with faculty to the development of professional attitudes and behaviour suggests that graduate programs which attempt to maximize this sort of interaction may produce more committed students [18]. A survey done by [16] relating to the likelihood of blowing the whistle among the races in Malaysia indicates that Malays are more likely to blow the whistle compared to other races.

\section{RESEARCH METHOD}

The data for the study is collected using primary source. Questionnaires were distributed to 150 final year accounting students in a public university in Malaysia. However, only 105 questionnaires were returned and usable for the purpose of the study. The questionnaire attempts to examine these students' perception of whistle blowing and their likelihood of blowing the whistle. The questionnaire used in this study is adopted from [2], [1] and [15]. In addition, short interviews were also conducted to better understand the issue under study.

Data was checked for normality, reliability, validity and multicollinearity. Regression analysis is employed to analyse the data. The regression model used in the study is as follows:

$\mathrm{PWB}=\alpha_{0}+\beta_{1} \mathrm{SQA}+\beta_{2} \mathrm{G}+\beta_{3} \mathrm{AP}+\beta_{4} \mathrm{RM}+\varepsilon$

Where:

PWB $=$ Probability of blowing the whistle

$\alpha=$ Constant

$\mathrm{SQA}=$ Seriousness of questionable act

$\mathrm{G}=\operatorname{Gender}($ Female $=1$, Male $=0)$

$\mathrm{AP}=$ Academic Performance

$\mathrm{RM}=\operatorname{Race}($ Malays $=1$, Non-Malays $=0)$

$\varepsilon \quad=\quad$ Error term 


\section{RESUlTS AND DisCUSSION}

Table I presents the demographic information of the respondents. The analysis of the profile indicates that more than majority $(73.3 \%)$ of the respondents are female and $26.7 \%$ of the respondents are male. About $49.5 \%$ of the respondents are Malays, $46.7 \%$ are Chinese and the balance is Indian. More than $37 \%$ of the respondents have CGPA between 3.51-4.00. Another $44 \%$ of the respondents have CGPA between 3.01-3.50, and the balance (18.1\%) has CGPA below 3.00.

TABLE I: DEMOGRAPHIC INFORMATION (N=105)

\begin{tabular}{|c|c|c|c|}
\hline \multicolumn{2}{|c|}{ Demographics } & \multirow{2}{*}{ Number of Respondents } & \multirow{2}{*}{$\frac{\text { Percentage }(\%)}{26.7}$} \\
\hline Gender: & Male & & \\
\hline & Female & 77 & 73.3 \\
\hline \multirow[t]{3}{*}{ Race: } & Malay & 52 & 49.5 \\
\hline & Chinese & 49 & 46.7 \\
\hline & Indian & 4 & 3.8 \\
\hline \multirow[t]{3}{*}{ CGPA: } & $3.51-4.00$ & 39 & 37.1 \\
\hline & $3.01-3.50$ & 47 & 44.8 \\
\hline & $<3.0$ & 19 & 18.1 \\
\hline
\end{tabular}

Table II shows the information about the respondents' perception on whistle blowing. The results in Table II indicate that final year accounting students are mostly moderate in their perception of whistle blowing. Short interviews with them reveal that, they may take the "wait and see" approach. They appear to understand the important of whistle blowing, but they would only do so if it is really necessary. Some of them reveal that if they encounter unethical conflicts, they would not act unethically nor would they blow the whistle. This result is similar to an earlier local study by [1]. They find that although the students would not prefer to indulge in unethical behaviour, but majority of them opt to be on the safe-side by neither act unethically nor blow the whistle.

TABLE II: PERCEPTION ON WHISTLE BLOWING

\begin{tabular}{|c|c|c|c|c|c|}
\hline Measures & $\mathbf{N}$ & Min & $\operatorname{Max}$ & Mean & $\begin{array}{c}\text { Std. } \\
\text { Deviation }\end{array}$ \\
\hline I think whistle blower is a hero. & 105 & 3 & 5 & 3.91 & 0.6219 \\
\hline $\begin{array}{l}\text { Whistle blowing upholds moral, } \\
\text { ethical practices and professionalism. }\end{array}$ & 105 & 3 & 5 & 3.96 & 0.5175 \\
\hline As a future accountant, ethical value is very important & 105 & 3 & 5 & 4.34 & 0.6017 \\
\hline I will likely to blow the whistle if I really need to do so & 105 & 3 & 5 & 4.09 & 0.5022 \\
\hline Whistle blower is a responsible corporate citizen. & 105 & 2 & 5 & 3.88 & 0.7030 \\
\hline $\begin{array}{l}\text { Whistle blower can help to decrease the } \\
\text { corruptions, fraud or mismanagement. }\end{array}$ & 105 & 2 & 5 & 4.02 & 0.7203 \\
\hline Whistle blowing encourages ethical behavior. & 105 & 2 & 5 & 3.97 & 0.6424 \\
\hline
\end{tabular}

TABLE III: PEARSON CORRELATION OF THE VARIABLES

\begin{tabular}{|c|c|c|c|c|c|}
\hline & 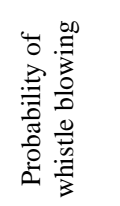 & 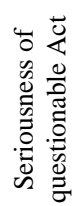 & 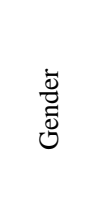 & 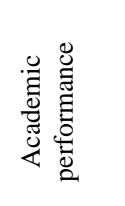 & $\underset{\mathscr{\Xi}}{\mathscr{\mathscr { Z }}}$ \\
\hline Probability of whistle blowing & 1.000 & & & & \\
\hline Seriousness of questionable act & $.434 * * *$ & 1.000 & & & \\
\hline Gender & $-.146^{*}$ & .060 & 1.000 & & \\
\hline Academic performance & $-.248 * * *$ & .074 & $.195^{* *}$ & 1.000 & \\
\hline Race & $.401 * * *$ & .027 & $-.178 * *$ & $-.432 * * *$ & 1.000 \\
\hline
\end{tabular}


The data is also checked for normality and multicollinearity before the regression analysis is carried out. Overall, the data analysed appears to be normally distributed as their skewness and kurtosis values are between \pm 3.00 [9]. Table III presents the pair wise correlation coefficient of all the variables used in the study. The results indicate that there is no multicollinearity problem, as the correlations are below the threshold value of 0.8 [7].

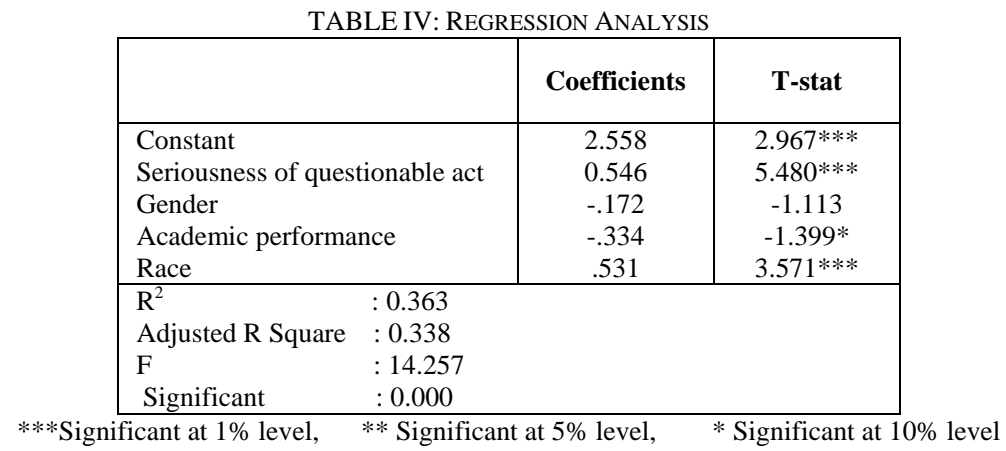

\section{Regression Analysis}

Table IV presents the regression results of the study. The value of the adjusted $\mathrm{R}$ - Squared is 0.338 , with the $\mathrm{F}$ value of 14.257 ( $p<0.000$ ). This adjusted R-squared is higher than the adjusted R-squared of a similar study by [10] which examines the business students' willingness to engage in whistle blowing. His study generates an adjusted R-squared of 0.264 .

Three of the four independent variables are significant in their relationship with the likelihood of blowing the whistle. The results indicate that there is a positive and significant relationship between the possibility of whistle blowing and the seriousness of the questionable act at $1 \%$ level of significant. This finding is consistent with [6] who claims that an individual would consider responding to an issue if that issue is serious enough to warrant consideration of response. From the answers in the questionnaires, the respondents cite as follows:

"if the unethical behavior will affect other human being seriously, then I will report it"

" if it gives a big effect to the company, then I will blow the whistle"

"my purpose to whistle blow is to protect our surrounding"

The second significant variable is academic performance. The result appears to suggest that high achiever future accountants are less likely to blow the whistle than the low achiever. This result contradicts the finding from an earlier study by [10]. Short interviews with these high achievers reveal the following:

"I will not whistle blow because I am afraid of being boycott or sack by the company",

"It may be necessary but I need to protect myself first"

"I will let the others do it first, see what is the feedback from the company"

These findings supports the earlier findings by [17] who reveals that some students generally feel that whistle blowing is necessary in cases of fraud, but they are less likely to do it themselves, probably due to the possibility of being sacks or other consequences of such behaviour, such as, the difficulty of finding a future job in the same profession. This is where the universities and faculties should play their roles to always motivate the students to act ethically. This can be done by integrating the ethics element in all the accounting courses or by exposing the students through the organisations of programs on ethical issues. It is also claimed that upon graduating, always keeping in contact with the faculty members may play a role in developing the professional commitment of the students as suggested by [18]. Frequent contact and interactions with faculty /university may help the development of professional attitudes and behaviour and produce more ethical and committed students [18].

The third significant variable is race. The result indicates that Malays are more likely to blow the whistle compared to non-Malays. This result is consistent with a study by [16]. [16] find that Malays are more likely to blow the whistle compared to other races. The plausible explanation for this finding is may be due to the fact that most of the Malays are Muslims, who practice Islamic values which uphold and encourages the good deeds and intention, honesty and being responsible persons. However, further investigation is needed before further conclusion can be made, which may provide an avenue for future research.

However, the other variable, gender of the accounting students is not significant in its relationship with the possibility of blowing the whistle. This is consistent with a prior study by [16] who finds an insignificant relationship between these variables.

\section{CONCLUSION AND LIMITATION}

The objective of this study is to examine the accounting students' perception on whistle blowing and their likelihood of blowing the whistle. The results indicate that the seriousness of the questionable act, academic performance and race are significantly related to the possibility of blowing the whistle. However, gender is not significant in its relationship with the probability of blowing the whistle. The finding also appears to indicate that majority of the respondents are taking a relatively moderate approach towards their willingness to blow the whistle. They appear 
to understand the need to act ethically and blow the whistle, but will only do so if it is really necessary. This highlights the importance of the ethic education, as well as the educators' and the university's role to continuously encourage and motivate the students to always act ethically and this attributes should be reflected in their work upon their graduation. Besides incorporating the ethic values in the courses in accounting program, organizing ethics related programs such as talks and seminars may also enhance ethical behaviour of students. In addition, universities can always keep in touch with the students (such as through alumni) to develop their professional commitment and behaviour to act ethically in their profession.

The findings from this study should be interpreted in the light of several limitations. Firstly, the data was collected from one university only, thus this limit the generalisation of the result. Further study may include other public as well as private universities in Malaysia. Secondly, the study used questionnaire, which focused on one particular period only. A longitudinal study on a specific cohort of students coming to the universities, possibly beginning from their first semester until graduation would address this problem.

Despite these limitations, this study contributes to the literature on ethical issues and helps to enhance our understanding on the ethical attitudes of accounting students.

\section{REFERENCES}

[1] N. B. Abu Bakar, S. Ismail, and S. Mamat, "Will graduating year accountancy students cheat in examination? A Malaysian case," International Education Studies, 2010, vol. 3, no. 3, pp. 145-152.

[2] S. A. Ahmad, M. Smith, and Z. Ismail. (August 2010). Internal whistle blowing intentions in Malaysia: Factors that influence internal auditors, decision-making process. [Online]. Available: http://www.internationalconference.com.my/proceeding/icber_procee ding/PAPER_104_InternalWhistleblowing.pdf .
[3] Z. Anwar. (August 2010).Whistle blowing: subversive spy or responsible corporate citizen? [Online]. Available: http://www.leesweeseng.com/whistleblowing/pdf .

[4] D. Banisar. (August 2010). "Whistle blowing international standards and developments." [Online]. Available: http://www.corrupcion.unam.mx/documentos/investigaciones/banisar _paper.pdf .

[5] L. Brewer, “The whistle-blower", Accountants Today, October 2005, pp. 10-12.

[6] M. B. Curtis, “Are ethical decisions dependent upon mood?” Journal of Business Ethics, 2006, vol. 68, pp. 191-209

[7] D. N. Gujarati, Basic econometrics, 4th ed. Singapore: McGraw Hill, 2003, pp. 359

[8] M. A. Khan, "Auditors and the whistle blowing law," Accountants Today, April 2009, pp. 12-14.

[9] R. B. Kline, "Principles and practice of Structural Equation Modelling," 2nd ed. New York: The Guilford Press, 2005, pp. 50

[10] R. A. Lawson, "Business students' willingness to engage in academic honesty and whistle blowing," Research on Professional Responsibility and Ethics in Accounting, 2004, vol. 9, pp. 1-19.

[11] E. Lee, "Whistleblowers: Heroes or villains?," Accountants Today, August 2005, pp. 14-18.

[12] J. P. Near and M. P. Miceli, "Organizational dissidence: The case of whistle-blowing," Journal of Business Ethics, 1985, vol. 4, no. 1, pp. $1-16$.

[13] J. P. Near and M. P. Miceli, "Whistle-blowing: myth and reality," Journal of Management, 1996, vol. 22, no. 3, pp. 507-526.

[14] C. O'Leary and D. Cotter, "The ethics of final year accountancy students: an international comparison." Managerial Auditing Journal, 2000, vol. 15, no. 3, pp. 108-115.

[15] B. Pierce and B. Sweeney, "The relationship between demographic variable and ethical decision making of trainee accountants,' International Journal of Auditing, 2009, vol. 14, pp. 79-99.

[16] C. H. Ponnu, , K. Naidu, and W. Zamri, "Determinants of whistle blowing," International Review of Business Research Papers, 2008, vol. 4, no. 1, pp. 276-298.

[17] E. Rafik, "Auditing students' professional commitment and anticipatory socialization and their relationship to whistle blowing," Managerial Auditing Journal, 2008, vol. 23, no. 3, pp. 283-294.

[18] C. S. Weiss, "The development of professional role commitment among graduate students," Human Relation, 1981, vol. 34, no. 1, pp. 13-31 